\title{
Conversion of organic residue from solid-state anaerobic digestion of livestock waste to produce the solid fuel through hydrothermal carbonization
}

\author{
Seung Kyu Yang, Daegi Kim, Seong Kuk Han, Ho Kim, Seyong Park \\ Bio Resource Team, Plant Engineering Division, Institute for Advanced Engineering, Yongin 17180, Republic of Korea
}

\begin{abstract}
The solid-state anaerobic digestion (SS-AD) has promoted the development and application for biogas production from biomass which operate a high solid content feedstock, as higher than $15 \%$ of total solids. However, the digested byproduct of SS-AD can be used as a fertilizer or as solid fuel, but it has serious problems: high moisture content and poor dewaterability. The organic residue from SS-AD has to be improved to address these problems and to make it a useful alternative energy source. Hydrothermal carbonization was investigated for conversion of the organic residue from the SS-AD of livestock waste to solid fuels. The effects of hydrothermal carbonization were evaluated by varying the reaction temperatures within the range of $180-240^{\circ} \mathrm{C}$. Hydrothermal carbonization increased the calorific value through the reduction of the hydrogen and oxygen contents of the solid fuel, in addition to its drying performance. Therefore, after the hydrothermal carbonization, the $\mathrm{H} / \mathrm{C}$ and $\mathrm{O} / \mathrm{C}$ atomic ratios decreased through the chemical conversion. Thermogravimatric analysis provided the changed combustion characteristics due to the improvement of the fuel properties. As a result, the hydrothermal carbonization process can be said to be an advantageous technology in terms of improving the properties of organic waste as a solid-recovered fuel product.
\end{abstract}

Keywords: Hydrochar production, Hydrothermal carbonization, Organic waste, Renewable solid fuel, Solid-state anaerobic digestion

\section{Introduction}

The current global energy issue of the depletion of the world's fossil fuel reserves due to the global consumption of coal has become a serious problem and is expected to become even more serious in the near future, with the impact of the global carbon dioxide emissions [1-2]. Renewable energy sources as biomass to bioenergy can provide a solution to this problem [2-5]. The biomass resources that can be used to produce bioenergy include various natural and derived materials such as including woody and herbaceous species, wood wastes, agricultural and industrial residues, waste paper, municipal solid waste (MSW), sawdust, bio-solids like sludge, grass, waste from food processing, animal wastes, aquatic plants, and algae [1-6].

Among the different biological treatment modalities, solid-state anaerobic digestion (SS-AD) has helped promote the development and application for biogas production from biomass. SS-AD is used in more than $60 \%$ of the existing anaerobic digesters in Europe [7-8]. It can operate a high solid content feedstock, as higher than $15 \%$ of total solids (TS). Consequently, SS-AD has the following advantage: a higher organic loading rate, a smaller reactor volume, a lower energy demand for heating, higher volumetric methane productivity, and less wastewater generation [8-10]. The result reported that SS-AD achieved a maximum methane yield of approximately $200 \mathrm{~L} / \mathrm{kg}$-volatile solids (VS) for the digestion of biomass containing $22 \%$ TS [11]. The digested byproduct of SS-AD can be used as a fertilizer or as solid fuel. It has serious problems, as a high moisture content and a poor dewaterability [7, 12]. The direct conventional thermal treatment methods, such as drying and combustion of byproduct need the high energy cost. The dewatering of the byproduct has to be improved to solve the aforementioned problem to make a useful alternative energy source.
This is an Open Access article distributed under the terms of the Creative Commons Attribution Non-Commercial License (http://creativecommons.org/licenses/by-nc/3.0/) which permits unrestricted non-commercial use, distribution, and reproduction in any medium, provided the original work is properly cited.

Copyright (C) 2018 Korean Society of Environmental Engineers
Received January 30, 2018 Accepted April 26, 2018

${ }^{\dagger}$ Corresponding author

Email: daegi.kim81@gmail.com, daegi.kim81@iae.re.kr Tel: +82-31-330-7218 Fax: +82-31-330-7111 ORCID: 0000-0003-3859-5065 
Hydrothermal carbonization (HTC) is one of the thermo-chemical treatment methods that are currently being used to convert organic materials and to improve their dewatering and upgrade their properties so that they can be used as cost effective and environment-friendly alternative fuels [13-14]. HTC has prompted the production of hydrochar and has improved the dewatering of several kinds of biomass resources [13-16]. In this study, after hydrothermal conversion, the fuel properties of the obtained products were investigated, including their calorific value and fuel properties. The aforementioned technique can apply to produce a homogeneous solid fuel, such as coal, which can be easily dewatered into a powdery fuel with a $10 \%$ moisture content [14-17]. Therefore, the moisture content of the sludge can be reduced to approximately $20 \%$ due to the breakdown of the physical structure [16-19]. This research was conducted to develop the HTC process that can convert SS-AD byproduct to an alternative fuel. The specific goals of this study were to investigate the effects of the reaction temperature on dewatering performance, to improve the fuel properties of the SS-AD byproduct through the HTC, and to determine the optimal reaction temperature of the HTC process.

\section{Materials and Methods}

\subsection{Materials}

The organic residue that was used in this study was derived from the lab-scale SS-AD of livestock waste. The lab-scale SS-AD test was conducted for one-stage mode, batch reactors in the form of $300 \mathrm{~mL}$ glass bottles. All experiments were performed in duplicate (a total of 30 samples). The initial TS of all SS-AD reactors were set to $20 \%$. The bottles were incubated at a mesophilic temperature $\left(37 \pm 1^{\circ} \mathrm{C}\right)$ for $30 \mathrm{~d}$. The biogas yield of the system produced $0.3-0.5 \mathrm{~m}^{3} / \mathrm{kg}$-volatile matter. Table 1 provides the characteristics of raw feedstock as livestock waste and organic residue.

Table 1. Characteristics of Organic Residue after SS-AD and Raw Cow Excrements (as before SS-AD)

\begin{tabular}{lcc}
\hline \multicolumn{1}{c}{ Contents } & $\begin{array}{c}\text { Raw cow } \\
\text { excrements }\end{array}$ & $\begin{array}{c}\text { Organic residue } \\
\text { after SS-AD }\end{array}$ \\
\hline Moisture (wt.\%) $^{\mathrm{a}}$ & 75.0 & 82.1 \\
\hline Proximate analysis (wt.\%) $^{\mathrm{b}}$ & & \\
Volatile matter & 73.5 & 68.5 \\
Fixed carbon & 9.1 & 10.9 \\
Ash & 17.4 & 20.6 \\
\hline Ultimate analysis (wt.\%) $^{\mathrm{b}}$ & & \\
Carbon & 49.1 & 44.9 \\
Hydrogen & 4.8 & 5.3 \\
Oxygen $^{\mathrm{c}}$ & 26.8 & 27.9 \\
Nitrogen $_{\text {Calorific value }(\mathrm{MJ} / \mathrm{kg})^{\mathrm{b}}}$ & 1.9 & 1.4 \\
\hline
\end{tabular}

${ }^{\mathrm{a}}$ as received, ${ }^{\mathrm{b}}$ on dry basis, ${ }^{\mathrm{c}}$ by difference

\subsection{Lab-scale Hydrothermal Carbonization Reactor}

A lab-scale HTC reactor was used to investigate the effects of the hydrothermal reaction temperatures. The experiments were performed using a 2,000 $\mathrm{mL}$ reactor consisting of a reactor body, a heater, and a steam condenser that operated under nitrogen gas. A $1,000 \mathrm{~mL}$ of SS-AD byproduct was mixed with a $300 \mathrm{~mL}$ of water and then loaded onto the reactor. The operating temperatures of the HTC reactor were $180-240^{\circ} \mathrm{C}$, and the reaction time was set to $30 \mathrm{~min}$, with a $200 \mathrm{rpm}$ agitation speed. After the completion of the hydrothermal reaction, the pressure and temperature were allowed to decrease to atmospheric pressure and room temperature, respectively, and the products were taken out of the reactor.

\subsection{Analytical Procedures}

The dewaterablity of the product of HTC was evaluated by measuring the capillary suction time (CST) and time to filter (TTF). The CST was determined using an improvised CST apparatus (model 319 Multi-purpose CST, Triton Electronics Ltd.) with single-radius test and CST paper (size: $79 \mathrm{~cm}$, quantity: 200 approx., Triton Electronics Ltd.). The TTF was measured according to the Standard Methods [20]. Organic residue of SS-AD and HTC hydrochars were prepared as powder-material which were sieved, and a fraction with a particle size between $177 \mu \mathrm{m}$ and $250 \mu \mathrm{m}$ was set aside for analysis. Elemental composition analysis of the sample was carried out using an EA 2400 Series II CHNS/O organic elemental analyzer (PerkinElmer, Waltham, MA, USA). Proximate analysis was conducted using a 5E-MAG6700 automatic proximate analyzer. The calorific value was determined using the bomb calorimetric standard method. The combustion characteristics were determined by using a thermogravimetric analyzer (TGA-Q500, TA Instruments). Non-isothermal combustion of the samples was conducted in the furnace of the TGA system at atmospheric pressure. The sample weight loss (TG) and the weight loss rate (DTG) were continuously recorded under a temperature range of $50-800^{\circ} \mathrm{C}$ and at a heating rate of $10^{\circ} \mathrm{C} / \mathrm{min}$.

\section{Results and Discussion}

\subsection{Improvement of the Dewaterability}

The SS-AD byproduct retained high moisture content, which is the primary challenge in the isolation of the organic materials after SS-AD. Interstitial water and surface water as bound water are held by capillary forces between the particles and cannot be easily separated by normal mechanical methods. In contrast, the free water surrounding the flocks can be easily removed. The improvement of the deweterability means that the bound water is converted to free water to remove the water content the organic residue of SS-AD. The organic residues of SS-AD consist of many particles in the flock as a single large particle, such as that with a sludge flock shape. The HTC process breaks up the physical structure of the slurry phase included in the sludge and biomass [17-19].

In this study, the CST analysis estimated the effects of the HTC in improving the dewaterability of the organic residues of SS-AD. The results of the CST and TTF analyses are shown 


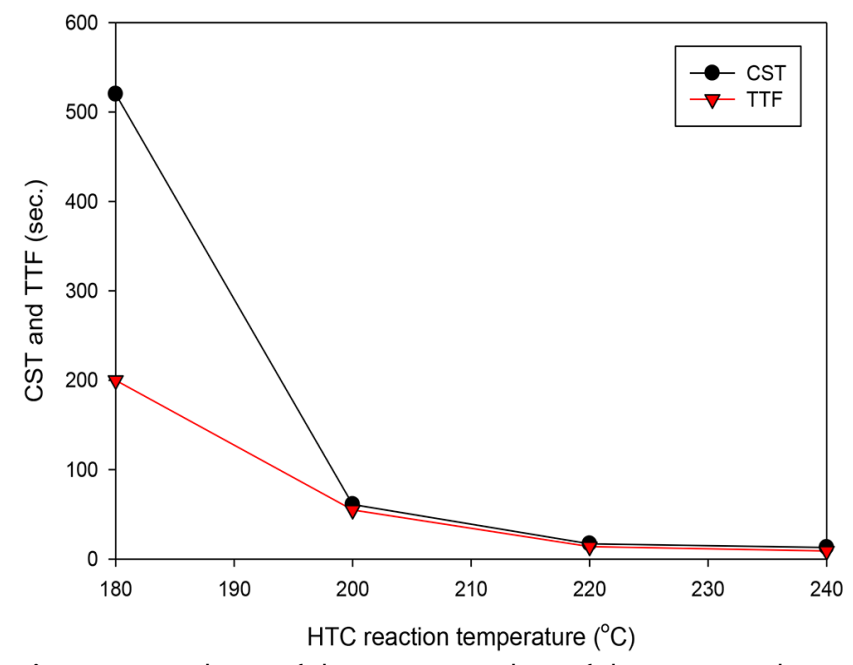

Fig. 1. CST and TTF of the organic residues of the SS-AD and HTC products by reaction temperatures.

in Fig. 1. CST and TTF analyses of raw organic residues of SS-AD are difficult to conduct because the slurry phase of the material is less accurate. In this study, the CST and TTF of the HTC product at $180^{\circ} \mathrm{C}$ were more than 520 and $200 \mathrm{~s}$, respectively. At above the $200^{\circ} \mathrm{C}$ of HTC reaction temperature, the CST and TTF were 61 and $55 \mathrm{~s}$ at $200^{\circ} \mathrm{C}$, and 17 and 14 $\mathrm{s}$ at $220^{\circ} \mathrm{C}$, respectively. The CST and TTF results closely corresponded to the presence of bound water content and hydrophobicity [17-18, 21]. HTC converted the physical structure of the organic residues of SS-AD, which were broken down to convert the bound water to free water. The decreasing CST and TTF owing to these influences confirmed that the HTC process increased the sludge dewaterability.

\subsection{Upgrading the Fuel Properties}

The properties of the organic residue of SS-AD and the HTC hydrochar are shown in Table 2. The raw organic residue of
SS-AD had a high volatile matter content (68.5\%). The volatile matter decreased as the reaction temperature increased, due to the chemical dehydration and decarboxylation reactions [14-16]. The raw organic residue of SS-AD indicated $10.9 \%$ of fixed carbon content and $68.5 \%$ of volatile matter content. After the HTC process, the fixed carbon content increased to $13.5 \%$ and $14.8 \%$, and the volatile matter content decreased to $59.3 \%$ and $54.2 \%$ at $200^{\circ} \mathrm{C}$ and $220^{\circ} \mathrm{C}$, respectively. As a result, the fuel ratio (fixed carbon/volatile matter) increased due to the hydrothermal carbonization reactions as 0.16 to 0.23 and 0.27 at $200^{\circ} \mathrm{C}$ and $220^{\circ} \mathrm{C}$, respectively. These results confirm that the HTC process was successful.

The elemental composition confirmed the improved fuel properties of the hydrochar from HTC. The carbon content of the hydrochar increased from $44.9 \%$ to $47.1 \%$ and $48.0 \%$ as the HTC reaction temperature increased at $200^{\circ} \mathrm{C}$ and $220^{\circ} \mathrm{C}$, respectively. The oxygen and hydrogen contents of the products were also reduced.

Furthermore, the reduction in the nitrogen content was predicted to eliminate the potential risk of forming chemicals such as $\mathrm{NO}_{\mathrm{x}}$. The nitrogen content decreased from $1.4 \%$ to $0.8 \%$, respectively. In the HTC reaction, the volatile-N was converted to the gas or liquid phase through devolatilization [15-17]. Moreover, this effect can reduce the $\mathrm{NO}_{\mathrm{x}}$ emission potential, thus producing a clean energy resource.

The Van Krevelen diagram confirmed that the coalification reaction of HTC has a significant effect on the elemental composition of the hydrochar as shown in Fig. 2. In this study, the atomic $\mathrm{H} / \mathrm{C}$ and $\mathrm{O} / \mathrm{C}$ ratios decreased as the HTC reaction temperature increased from $180^{\circ} \mathrm{C}$ to $240^{\circ} \mathrm{C}$.

The atomic $\mathrm{H} / \mathrm{C}$ and $\mathrm{O} / \mathrm{C}$ ratios decreased from 1.3 and 0.5 to 1.1 and 0.3 , respectively, as the reaction temperature increased from $180^{\circ} \mathrm{C}$ to $240^{\circ} \mathrm{C}$. The slope of the regression line was 1.164 , indicating reduced atomic $\mathrm{H} / \mathrm{C}$ and $\mathrm{O} / \mathrm{C}$ ratios, which confirmed the occurrence of dehydration and decarboxylation reactions during HTC. The results of hydrochar showed properties approaching between lignite and sub-bituminous coal properties as the HTC

Table 2. The Characteristics of Hydrochar from Organic Residue of SS-AD by HTC Reaction Temperatures

\begin{tabular}{|c|c|c|c|c|c|}
\hline \multirow{2}{*}{ Contents } & \multirow{2}{*}{$\begin{array}{c}\text { Raw } \\
\text { (SS-AD) }\end{array}$} & \multicolumn{4}{|c|}{ Hydrochar } \\
\hline & & HTC $180^{\circ} \mathrm{C}$ & HTC $200^{\circ} \mathrm{C}$ & HTC $220^{\circ} \mathrm{C}$ & HTC $240^{\circ} \mathrm{C}$ \\
\hline Moisture (wt. \%) ${ }^{\mathrm{a}}$ & 82.1 & 83.8 & 84.2 & 84.6 & 81.8 \\
\hline \multicolumn{6}{|l|}{ Proximate analysis (wt.\%) } \\
\hline Fixed carbon & 10.9 & 12.0 & 13.5 & 14.8 & 16.3 \\
\hline Volatile matter & 68.5 & 63.9 & 59.3 & 54.2 & 48.3 \\
\hline Ash & 20.6 & 24.1 & 27.2 & 31.0 & 35.4 \\
\hline \multicolumn{6}{|l|}{ Ultimate analysis (wt.\%) } \\
\hline Carbon & 44.9 & 45.1 & 47.1 & 48.0 & 49.7 \\
\hline Hydrogen & 5.3 & 5.1 & 4.9 & 4.5 & 4.1 \\
\hline Oxygenc & 29.8 & 24.6 & 20.0 & 15.7 & 10.1 \\
\hline Nitrogen & 1.4 & 1.1 & 0.8 & 0.8 & 0.7 \\
\hline Calorific value $(\mathrm{MJ} / \mathrm{kg})^{\mathrm{b}}$ & 19.4 & 20.4 & 22.5 & 22.4 & 23.1 \\
\hline
\end{tabular}

\footnotetext{
${ }^{\mathrm{a}}$ as received, ${ }^{\mathrm{b}}$ on dry basis, ${ }^{\mathrm{c}}$ by difference
} 


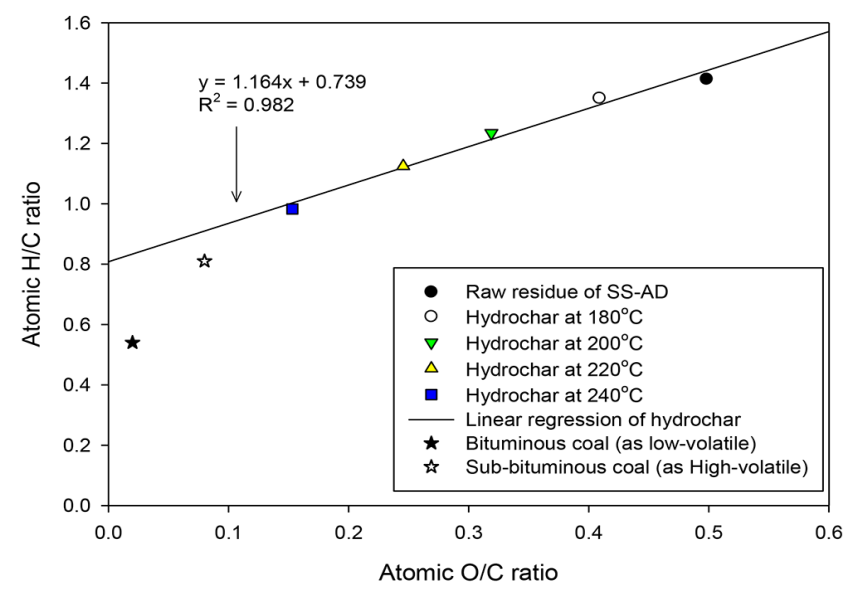

Fig. 2. The Van Krevelen diagram of hydrochar from organic residue of SS-AD by HTC.

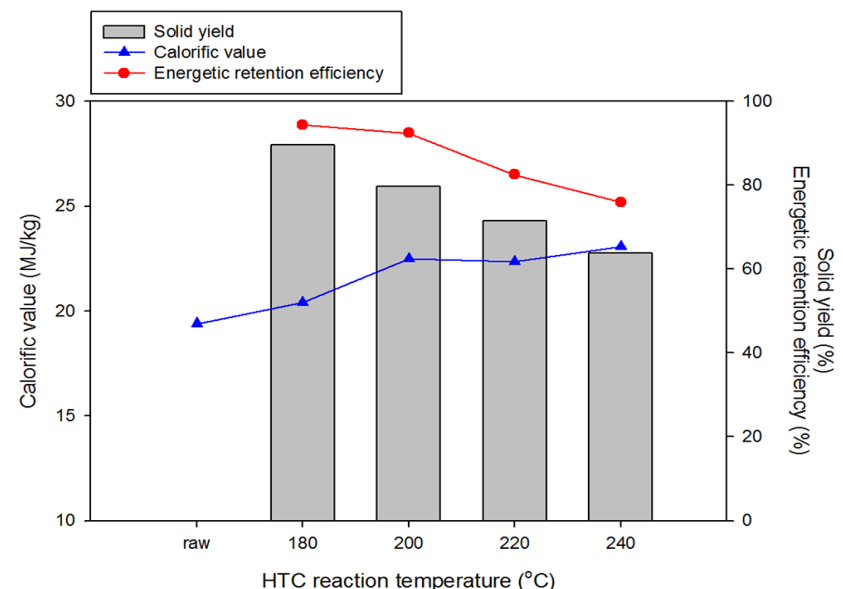

Fig. 3. Energy balance of organic residue of SS-AD and hydrochars by HTC temperatures: Calorific value, solid yield, and energetic retention efficiency.

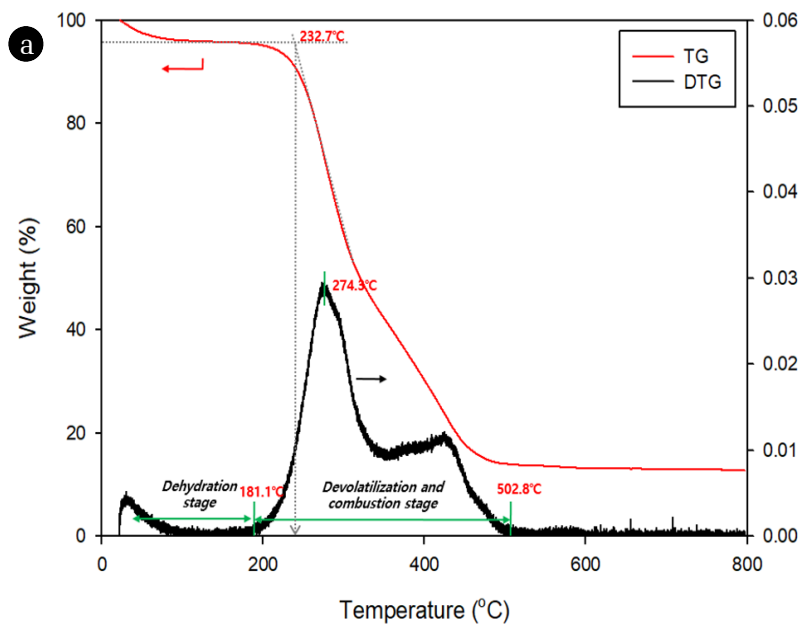

reaction temperature increased [22-23]. These results suggest that HTC can improve the properties of hydrochar from organic residue of SS-AD. As a result, the elevated carbon and fixed carbon contents can be said to have a strong influence on the calorific value [24-25]. The calorific values of the hydrochar from the organic residue of SS-AD were improved from 19.4 to $20.4 \mathrm{MJ} / \mathrm{kg}$ at $180^{\circ} \mathrm{C}, 22.4 \mathrm{MJ} / \mathrm{kg}$ at $200^{\circ} \mathrm{C}, 22.5 \mathrm{MJ} / \mathrm{kg}$ at $220^{\circ} \mathrm{C}$, and $23.1 \mathrm{MJ} / \mathrm{kg}$ at $240^{\circ} \mathrm{C}$, respectively (as shown in Fig. 3), and the influence of HTC was estimated by calculating the energy-related properties associated with the solid yield, including the energetic retention efficiency as follows Eq. (1) to (2):

Solid yield $=$

(Mass of dried solid recovered (hydrochar))/

(Mass of dried initial feedstock)

Energetic retention efficiency $=$

(Calorific value of hydrochar)/

(Calorific value of feedstock)·Solid yield

The energetic retention efficiency can provide the optimum condition of the HTC reaction to the hydrochar production solid fuel. The increasing reaction temperatures influenced the rising calorific value of the hydrochar, but the product yield of the hydrochar decreased due to the dehydration and decarboxylation (as converted to $\mathrm{CO}_{2}$ and $\mathrm{H}_{2} \mathrm{O}$ ) reactions [14-16]. As shown in Fig. 3, the highest energetic retention efficiency of a given material was $94.3 \%$ at $180^{\circ} \mathrm{C}$ of HTC. However, this HTC reaction temperature was not enough to improve the dewaterability. Therefore, the optimum reaction temperature of HTC for the organic residue of SS-AD was found to be $200^{\circ} \mathrm{C}$, which was $91.9 \%$ of the energetic retention efficiency with which the improvement of dewaterability can start.

\subsection{Combustion Behavior of Organic Residue of SS-AD and Hydrochar}

Fig. 4 compares the TG and DTG profiles of the organic residue of SS-AD and the hydrochar of HTC at $200^{\circ} \mathrm{C}$ as the optimum

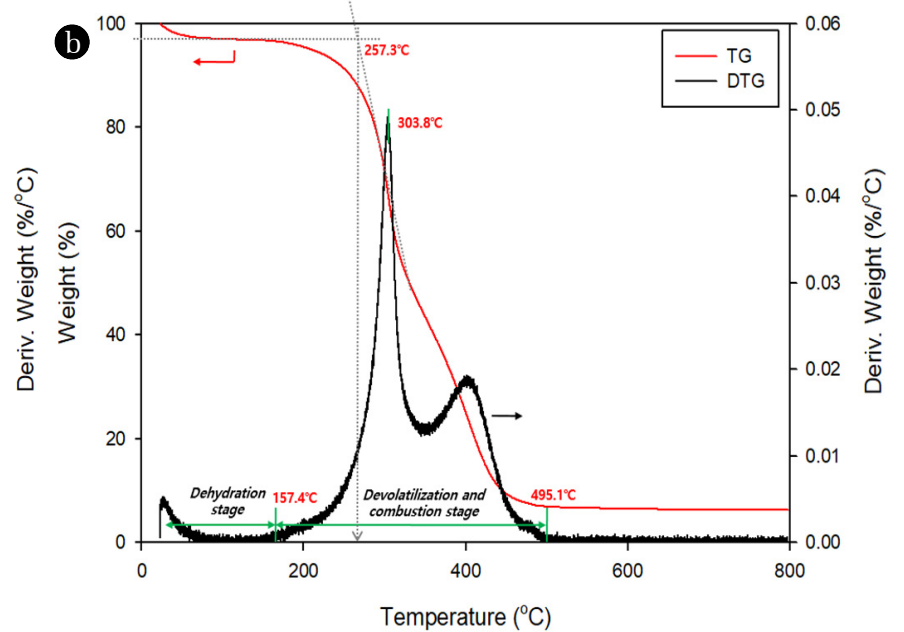

Fig. 4. Comparison of the TG and DTG curves of the combustion profiles of (a) the organic residue of SS-AD and (b) hydrochar at $200^{\circ} \mathrm{C}$ of HTC. 
temperature. The combustion characteristics were compared based on three characteristic temperatures: the ignition temperature (Ti), the maximum combustion rate temperature (Tm), and the burnout temperature (Tb) as determined from the TG and DTG curves. Ti provides the temperature at which fuels start to burn; Tm corresponds to the highest DTG peak temperature; $\mathrm{Tb}$ provides the temperature at which the weight loss diminishes at a rate of $1 \% / \mathrm{min}$ [26-27]. Ti increased from $232.7^{\circ} \mathrm{C}$ to $257.3^{\circ} \mathrm{C}$, and $\mathrm{Tm}$ also increased from $274.3^{\circ} \mathrm{C}$ to $303.8^{\circ} \mathrm{C}$ due to decreased volatile matter owing to the HTC reaction. Tb decreased from $502.8^{\circ} \mathrm{C}$ to $495.1^{\circ} \mathrm{C}$. The different combustion behaviors between the organic residue of SS-AD and hydrochar were shown by several stages depending on the rate of weight loss of the DTG curve (i.e., dehydration stage, the devolatilization stage, and combustion stage). As a result, the combustion range of the hydrochar was extended at the devolatilization and combustion stages due to the increased fixed carbon content. Moreover, the dehydration range decreased from $181.1^{\circ} \mathrm{C}$ to $157.4^{\circ} \mathrm{C}$, which resulted in the improvement of the chemical drying performance of the organic residue of SS-AD.

\section{Conclusions}

HTC was used to convert the organic residue of SS-AD from livestock waste into an alternative solid fuel with high energy efficiency. After the completion of HTC, further treatment was performed to break down the physical structure of the organic residue of SS-AD to improve the dewaterability as released free water. Moreover, the organic residue of SS-AD obtained through HTC significantly increased the carbon and fixed carbon contents with respect to the calorific values due to the dehydration and decarboxylation reactions. The Van Krevelen diagram, which provided the $\mathrm{H} / \mathrm{C}$ and $\mathrm{O} / \mathrm{C}$ ratios decreased, in correlation with the primary reactions of coalification. Furthermore, the optimum reaction temperature of HTC for the organic residue of SS-AD was found to be $200^{\circ} \mathrm{C}$, which was $91.9 \%$ of the energetic retention efficiency with which the improvement of the dewaterability can be started. The thermogravimetric analysis also confirmed the improvement of the combustion characteristics through HTC.

\section{Acknowledgments}

This work was supported by Korea Institute of Planning and Evaluation for Technology in Food, Agriculture, Forestry and Fisheries (IPET) through Agri-Bio Industry Technology Development Program, funded by Ministry of Agriculture, Food and Rural Affairs (MAFRA) (Project No.: 314010-4).

\section{References}

1. Paiano A, Lagioia G. Energy potential from residual biomass towards meeting the EU renewable energy and climate targets. The Italian case. Energ. Policy 2016;91:161-173.
2. Leitner W, Quadrelli EA, Schlögl R. Harvesting renewable energy with chemistry. Green Chem. 2017;19:2307-2308.

3. Yahya M, Fudholi A, Sopian K. Energy and exergy analyses of solar-assisted fluidized bed drying integrated with biomass furnace. Renew. Energ. 2017;105:22-29.

4. Woldeyohannes AD, Woldemichael DE, Baheta AT. Sustainable renewable energy resources utilization in rural areas. Renew. Sust. Energ. Rev. 2016;66:1-9.

5. Saleh TA. Simultaneous adsorptive desulfurization of diesel fuel over bimetallic nanoparticles loaded on activated carbon. J. Clean. Prod. 2018;172:2123-2132.

6. Dunjic S, Pezzutto S, Zubaryeva A. Renewable energy development trends in the Western Balkans. Renew. Sust. Energ. Rev. 2016;65:1026-1032.

7. Li Y, Park SY, Zhu J. Solid-state anaerobic digestion for methane production from organic waste. Renew. Sust. Energ. Rev. 2011;15:821-826.

8. Ge X, Xu F, Li Y. Solid-state anaerobic digestion of lignocellulosic biomass: Recent progress and perspectives. Bioresour. Technol. 2016;205:239-249.

9. Saleh TA. Nanotechnology in oil and gas industries: Principles and applications. Saleh TA, ed. Springer; 2017.

10. Yang L, Xu F, Ge X, Li Y. Challenges and strategies for solid-state anaerobic digestion of lignocellulosic biomass. Renew. Sust. Energ. Rev. 2015;44:824-834.

11. Khalid A, Arshad M, Anjum M, Mahmood T, Dawson L. The anaerobic digestion of solid organic waste. Waste Manage. 2011;31:1737-1744.

12. Zhang Z, Li W, Zhang G, Xu G. Impact of pretreatment on solid state anaerobic digestion of yard waste for biogas production. World J. Microbiol. Biotechnol. 2014;30:547-554.

13. Liu Z, Balasubramanian R. Upgrading of waste biomass by hydrothermal carbonization (HTC) and low temperature pyrolysis (LTP): A comparative evaluation. Appl. Energ. 2014;114:857-864.

14. Funke A, Ziegler F. Hydrothermal carbonization of biomass: A summary and discussion of chemical mechanisms for process engineering. Biofuel. Bioprod. Bior. 2010;4:160-177.

15. Kim D, Lee K, Park KY. Hydrothermal carbonization of anaerobically digested sludge for solid fuel production and energy recovery. Fuel 2014;130:120-125.

16. Hoekman SK, Broch A, Robbins C. Hydrothermal carbonization (HTC) of lignocellulosic biomass. Energ. Fuel. 2011;25:1802-1810.

17. Kim D, Prawisudha P, Yoshikawa K. Hydrothermal upgrading of Korean MSW for solid fuel production: Effect of MSW composition. J. Combust. 2012;2012:1-8.

18. Favas G, Jackson WR. Hydrothermal dewatering of lower rank coals. 2. Effects of coal characteristics for a range of Australian and international coals. Fuel 2003;82:59-69.

19. Kim D, Lee K, Park KY. Upgrading the characteristics of biochar from cellulose, lignin, and xylan for solid biofuel production from biomass by hydrothermal carbonization. J. Ind. Eng. Chem. 2016;45:95-100.

20. APHA, WEF 2012. Standard methods for the examination of water and wastewater 22. 2012.

21. Mathlouthi M. Water content, water activity, water structure 
and the stability of foodstuffs. Food Control 2001;12:409-417.

22. Baxter L. Biomass-coal co-combustion: Opportunity for affordable renewable energy. Fuel 2005;84:1295-1302.

23. Yadav V, Baruah BP, Khare P. Comparative study of thermal properties of bio-coal from aromatic spent with low rank sub-bituminous coals. Bioresour. Technol. 2013;137:376-385.

24. Sabio E, Álvarez-Murillo A, Román S, Ledesma B. Conversion of tomato-peel waste into solid fuel by hydrothermal carbonization: Influence of the processing variables. Waste Manage. 2016;47:122-132.
25. Raj T, Kapoor M, Gaur R, et al. Physical and chemical characterization of various Indian agriculture residues for biofuels production. Energ. Fuel. 2015;29:3111-3118.

26. Zhang K, Zhang K, Cao Y, Pan WP. Co-combustion characteristics and blending optimization of tobacco stem and high-sulfur bituminous coal based on thermogravimetric and mass spectrometry analyses. Bioresour. Technol. 2013;131:325-332.

27. Toptas A, Yildirim Y, Duman G, Yanik J. Combustion behavior of different kinds of torrefied biomass and their blends with lignite. Bioresour. Technol. 2015;177:328-336. 